\title{
Penerapan Green Supply Chain Management Untuk Peningkatan Kinerja Keuangan Perusahaan
}

\author{
Daniel Alfa Puryono ${ }^{a^{*}}$, Mustafid $^{b}$, Ferry Jie $^{\mathrm{c}}$ \\ a STIMIK AKI Pati \\ ${ }^{\mathrm{b}}$ Fakultas Sains dan Matematika, Universitas Diponegoro

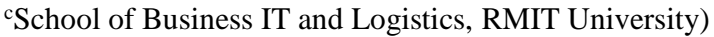

Naskah Diterima : 27 April 2016; Diterima Publikasi : 11 Juni 2016

DOI: $10.21456 /$ vol6iss2pp154-163

\begin{abstract}
In this research the assessment of the processes green supply chain management for corporate financial performance improvement. This research was based on the company goal to achieve profit by lowering the risk and environmental impact while improving the ecological efficiency by implementing green supply chain management in order to improve the company's financial performance. The method used in this research is a Green Supply Chain Management (GSCM). The management process of the company was done with by giving weight to the indicators of the green supply chain and measuring supply chain performance by using AHP method. Then compared with the acquired real weight of the Green SCOR model. While to measuring the financial performance of the company to know the position of the company by using ROA and EVA calculation that exist in the methods of Du Pont Ratio Analysis. The results of this research is a decision system information which is capable of linking green supply chain performance with the company's financial performance. The results of the analysis indicated that the supplying, making, delivering and returning are very sustainable. The assessment result shows $87.3 \%$ of companies have increased the company's financial and $12.7 \%$ companies' efficiency. This information system can be developed to assist the manager in the company's decision-making started from the sustainable design. This research method can be developed to assess the extent of each indicator of the supply chain performance related to the financial strategies.
\end{abstract}

Keyword : GSCM; AHP; Green SCOR; Du Pont Ratio Analysis

\begin{abstract}
Abstrak
Pada penelitian ini telah dilakukan penilaian terhadap proses rantai pasok yang ramah lingkungan, kinerja rantai pasok dan kinerja keuangan. Penelitian ini didasarkan pada pola dasar perusahaan untuk mencapai keuntungan dengan cara menurunkan risiko dan dampak lingkungan sekaligus meningkatkan efesiensi ekologi. Dengan cara menerapkan manajemen rantai pasok yang ramah lingkungan untuk meningkatkan kinerja keuangan perusahaan. Metode yang digunakan pada penelitian ini adalah manajemen rantai pasok yang ramah lingkungan. Proses pengelolaan pada perusahaan dilakukan dengan urutan : memberi bobot pada indikator proses rantai pasok yang ramah lingkungan, mengukur kinerja rantai pasok dengan mengunakan metode AHP. Kemudian di bandingkan dengan perolehan bobot riil dari model SCOR. Selanjutnya untuk mengukur kinerja keuangan perusahaan dan mengetahui posisi perusahaan dengan mengunakan perhitungan model ROA dan EVA yang ada dalam metode Du Pont Ratio Analysis. Hasil dari penelitian ini adalah sebuah sistem informasi pengambilan keputusan yang mampu menguhungkan antara kinerja rantai pasok yang ramah lingkungan dengan kinerja keuangan perusahaan. Dari hasil analisa menunjukkan bahwa pengadaan, produksi, pengiriman dan pengembalian sangat ramah lingkungan. Serta hasil penilaian menunjukan $87,3 \%$ perusahaan mengalami peningkatan keuangan dan $12,7 \%$ perusahaan efesien. Sitem informasi ini dapat dikembangkan untuk membantu para menejer perusahaan dalam pengambilan keputusan mulai dari tahap perencanaan yang ramah lingkungan. Metode penelitian ini dapat dikembangkan untuk menilai sejauh mana setiap kategori kinerja rantai pasok terkait dengan strategi keuangan.
\end{abstract}

Kata Kunci : GSCM; AHP; Green SCOR; Du Pont Ratio Analysis

\section{Pendahuluan}

Dalam beberapa tahun terakhir, Green Supply Chain Management (GSCM) menjadi salah satu strategi yang penting untuk mencapai pembangunan yang berkesinambungan bagi perusahaan (Kurien et al., 2012). Konsep GSCM merupakan manajemen rantai pasokan yang berhubungan dengan aspek lingkungan. Manajemen rantai pasokan yang berbasis "green" penting untuk diterapkan karena selama ini ukuran kinerja rantai pasokan biasanya tidak memperhatikan dampak terhadap lingkungan.

*) Penulis korespondensi: danielsempurna@gmail.com 
Sejalan dengan tujuan utama perusahaan yaitu untuk memaksimalkan keuntungan serta dapat mengukur dan memantau tujuan organisasi serta memperhatikan lingkungan, hal ini dapat dicapai melalui identifikasi untuk meningkatkan kinerja. Sedangkan pengukuran kinerja didefinisikan sebagai proses mengukur efektivitas dan efisiensi dari tindakan (Wong et al., 2011).

Perusahaan juga tidak akan mampu bersaing atau bertahan kecuali mereka mengembangkan strategi untuk mencapai pengurangan biaya, peningkatan kualitas dan peningkatan produktivitas (Tipi et al., 2012). Permasalahanya adalah bagaimana mengelola hubungan timbal balik antar strategi karena biasanya menerapkan strategi untuk mencapai pengurangan biaya bisa berdampak negatif terhadap kualitas atau mengakibatkan penurunan produktivitas.

Oleh karena itu mengukur kinerja perusahaan dengan menggunakan serangkaian langkah-langkah keuangan menjadi solosi. Dengan cara mengidentifikasi faktor-faktor untuk mengukur keuangan secara akurat agar dapat memprediksi kinerja perusahaan dan bahkan megambil keputusan yang tepat bagi perusahaan (Delen et al., 2013).

Metode seperti pembobotan yang berkaitan dengan proses pengambilan keputusan seperti Analytic Hierarchy Process (AHP) (Chen et al., 2012) model Supply Chain Operations Reference (SCOR) (Tipi et al., 2012) serta (Wang et al., 2012) Mixed Integer Linear Programming (MILP) (Povoa et al., 2013) Interpretive Structural Modeling (ISM) (Giovanni et al., 2012). Banyak digunakan untuk memfasilitasi proses GSCM. Namun metode seperti MILP dan ISM masih banyak kelemahan jika di imlepentasikan dengan manjemen yang ramah lingkungan.

Penelitian ini memiliki perbedaan dengan penelitipeneliti yang terdahulu. Perbedaan tersebut terletak pada analisis yang digunakan yaitu model Green SCOR untuk meningkatkan kinerja rantai pasok dan kinerja keuangan perusahaan yang mempertimbangkan faktor lingkungan. serta dapat mengetahui dimensi-dimensi perioritas keuangan perusahaan. Model Green SCOR, AHP dan Du pont ratio analysis dapat memecahkan masalah pada metode ISM dan MILP yaitu faktor kualitatif maupun penerapan GSCM pada industri manufaktur.

\section{Kerangka Teori}

\subsection{Supply Chain Operations Reference (SCOR)}

Model SCOR merupakan acuan dari operasi rantai pasokan yang berdasarkan proses. Model ini menyediakan kerangka kerja manajemen rantai pasokan yang konsisten, termasuk proses bisnis, evaluasi kinerja dan praktik perbaikan. Hal ini dapat membantu semua komponen dari rantai pasokan, termasuk produsen, pemasok, pengecer, distributor, penyedia layanan logistik dan pelanggan, untuk meningkatkan efisiensi manajemen rantai pasokan dengan berkomunikasi secara efektif (Supply Chain Council, 2010).

Lingkup dari proses SCOR adalah :

1. Plan (perencanaan dan manajemen dari permintaan ataupun pasokan).

2. Source (Pengadaan persediaan, membuat permintaan)

a. Jadwal pengiriman, penerimaan, memverifikasi dan mengirim produk serta mengesahkan pembayaran pengadaan, juga mengaturan bisnis langsung, menilai kinerja pengadaan dan menyimpan data.

b. Mengelola persediaan, jaringan pengadaan, persyaratan impor / ekspor, dan perjanjian pengadaan.

3. Make (proses yang mengubah produk ke tahap selesai) meliputi penjadwalan, pengolahan, pengujian, pengemasan, pengiriman, mengatur aturan dan kepatuhan terhadap peraturan produksi.

4. Deliver : termasuk pemesanan dan faktur dari pelanggan, manajemen transportasi (pengiriman), strategi distribusi, menerima dan memverifikasi produk, logistik, ekspor dan persyaratan impor.

5. Return (pengembalian bahan baku (pengadaan) dan pengembalian barang jadi (dari pelanggan) untuk setiap alasan, termasuk produk cacat).

Sedangkan untuk mengukur kinerja dari rantai pasok ada lima kategori yaitu reliability (kehandalan), responsiveness (daya tangkap), aglity (mudah menyesuaikan), cost (biaya) dan asset management (aset).

Langkah berikutnya adalah menyeleksi matrik kriteria tersebut menjadi Key Performance Indicator (KPI). Karena sebuah perusahaan tidak bisa menjadi yang terbaik di semua mertik, jadi harus bijak menargetkan kekuatan di beberapa bidang saja (Huang et al., 2005).

Konsep dari Green SCOR cukup sederhana karena merupakan modifikasi dari model SCOR yaitu mengefektifkan manajemen rantai pasokan dan dibangun dengan memasukkan unsur-unsur sistem manajemen lingkungan. Tujuannya yaitu untuk menciptakan suatu alat analisis yang memberikan gambaran tentang hubungan antara fungsi rantai pasokan dengan aspek lingkungan agar tercipta peningkatan kinerja manajemen diantara keduanya (Wilkerson et al., 2003 dan SCC, 2010).

\subsection{Analytical Hierarchy Process (AHP)}

Pada AHP keputusan diambil dengan cara membandingkan secara berpasangan alternatifalternatif yang akan dipilih dengan menggunakan kuisioner. AHP menangani berbagai perspektif (kriteria) dan tindakan (sub kriteria) dengan derajat yang berbeda kepentingan dan menerjemahkan hasil keseluruhan menjadi matrik terpadu. Hasil yang diperoleh adalah memungkinkan para manajer untuk 
mengetahui berbagai perspektif dari penilaian kinerja dan memahami kemungkinan kegagalan.

Langkah-langkahnya adalah sebagai berikut :

1. Menyusun hirarki dari permasalahan yang dihadapi.

Persoalan yang akan diselesaikan, diuraikan menjadi unsur-unsurnya yaitu kriteria dan alternatif kemudian disusun menjadi struktur hierarki.

2. Penilaian kriteria dan alternatif.

Kriteria dan alternatif dinilai melalui perbandingan berpasangan untuk berbagai persoalan. Skala 1 sampai 9 adalah skala terbaik dalam mengekspresikan pendapat.

3. Penentuan Prioritas.

Nilai-nilai perbandingan relatif kemudian diolah untuk menentukan peringkat alternatif dari seluruh alternatif.

4. Konsistensi Logis.

Dalam pembuatan keputusan, penting untuk mengetahui seberapa baik konsistensi yang ada, karena kita tidak menginginkan keputusan berdasarkan pertimbangan dengan konsistensi yang rendah. Hal ini dapat dilakukan dengan langkah adalah :

a. Mengkalikan setiap nilai pada kolom pertama dengan elemen prioritas pertama, nilai pada kolom kedua dengan elemen prioritas kedua, dan seterusnya.

b. Menjumlahkan setiap baris.

c. Hasil dari penjumlahan baris dibagi dengan elemen prioritas yang bersangkutan.

d. Jumlahkan hasil bagi diatas dengan banyaknya elemen yang ada, hasilnya disebut $\lambda_{\text {maks }}$

e. $\lambda_{\text {maks }}=$ nilai eigen terbesar dari matrik berordo $\mathrm{n}$.

f. Nilai eigen terbesar didapat dengan menjumlahkan hasil perkalian jumlah kolom dengan eigen vector. Batas ketidak konsistenan diukur dengan menggunakan rasio konsistensi (CR), yakni perbandingan indeks konsistensi (CI) dengan nilai konsistensi acak (RI). Nilai ini bergantung pada ordo matrik $n$.

g. Menghitung consistency index (CI) dengan rumus :

$$
C I=\frac{\lambda_{m a k s}-n}{n-1}
$$

Dimana $\mathrm{n}$ adalah banyaknya elemen.

$\lambda_{\text {maks }}=$ harga rata-rata yang dihitung sebelumnya.

Jika CI = 0 maka pengambil keputusan adalah konsisten sempurna. Sedangkan seberapa jauh inkonsistensi tersebut dapat diterima. Maka harus dibandingkan CI dengan indeks random yaitu indeks konsistensi dari matriks komparasi pasangan secara random. Harga RI dapat dilihat pada Tabel 1
Tabel 1. Harga Random Index

\begin{tabular}{|c|c|c|c|c|c|c|c|c|c|}
\hline $\mathbf{N}$ & 2 & 3 & 4 & 5 & 6 & 7 & 8 & 9 & 10 \\
\hline $\mathbf{R I}$ & 0 & 0,58 & 0,90 & 1,12 & 1,24 & 1,32 & 1,41 & 1,45 & 1,51 \\
\hline
\end{tabular}

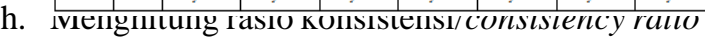

(CR) dengan rumus :

$C R=\frac{C I}{I R}$

dimana :

$\mathrm{CR}=$ Consistency Ratio

$\mathrm{CI}=$ Consistensy Index

$\mathrm{IR}=$ Index Random Consistency

i. Memeriksa konsistensi hierarki, jika nilainya lebih dari 10\%, maka penilaian data judgement harus diperbaiki. Namun jika rasio konsistensi (CI/IR) kurang atau sama dengan 0,1 maka hasil perhitungan bisa dinyatakan benar (Chen et al., 2012).

\subsection{Kinerja Keuangan}

Kinerja keuangan merupakan usaha formal yang dilakukan oleh perusahaan untuk dapat mengukur keberhasilan suatu perusahaan dalam menghasilkan laba, sehingga dapat melihat prospek, pertumbuhan, dan potensi perkembangan perusahaan dengan mengandalkan sumber daya yang ada (Delen et al., 2013).

Du Pont Ratio Analysis merupakan metode rasio keuangan yang umum digunakan untuk mengukur kinerja keuangan organisasi (Tipi et al., 2012). Dalam penelitian ini digunakan untuk mengevaluasi bidang profitabilitas dan efisiensi operasional dengan menilai komponen kinerja yang berberkontribusi untuk Return On Assets (ROA) yang didalamnya merupakan pendapatan (penjualan), biaya dan total aset.

ROA mengukur berapa banyak keuntungan perusahaan yang dihasilkan kemudian dibandingkan dengan aset yang digunakan dalam bisnis yang terdiri dari profitabilitas (Net Profit Margin) dan efisiensi (Total Assets Turnover) dapat dinyatakan dalam rumus sebagai berikut :

$$
\begin{aligned}
\mathrm{ROA} & =\text { Net Profit Margin } \times \text { Total Assets Turnover } \\
& =(\text { Net Income/Sales }) \times(\text { Sales/Total Assets })
\end{aligned}
$$

Sedangkan untuk mengetahui indeks keuangan perusahaan apakah baik atau dalam posisi gawat yaitu dengan menggunakan komponen (Economic Value Added) EVA. Cara yaitu dengan menilai kontribusi masing-masing komponen kinerja keuangan yaitu pendapatan, biaya, dan aset (revenue, cost, and assets) terhadap peningkatan profitabilitas dan efisiensi operasional perusahaan.

Dapat dinyatakan dalam rumus sebagai berikut :

EVA $=$ NOPAT- Capital Charges

Dimana :

NOPAT = Net Operating After Tax

Capital Charges = Invested Capital atau Cost Of Capital 
Ketentuan penilaian kinerja keuangan sebagai berikut :

Jika EVA > 0, maka kinerja keuangan perusahaan dapat dikatakan baik, karena kreditur tetap mendapat bunga dan pemilik saham bisa mendapatkan pengembalian yang sama atau lebih dari yang ditanam.

Jika EVA =0, maka secara ekonomis "impas" karena semua laba digunakan untuk membayar kewajiban kepada penyandang dana baik kreditur maupun pemegang saham.

Jika EVA $<0$, maka kinerja keuangan perusahaan tersebut dikatakan tidak sehat, karena perusahaan tidak bisa memberikan nilai tambah. Bahkan kreditur tetap mendapat bunga dan pemilik saham tidak mendapat pengembalian yang sepadan dengan yang ditanam.

\section{Metodologi}

\subsection{Bahan dan Alat Penelitian}

Penelitian ini mengunakan data yang diperoleh dari laporan keuangan serta data dari bagian gudang, logistik dan TUK yang akan diolah dengan mengunakan kerangka model Green SCOR. Selain itu juga mengunakan data dari kuesioner yang akan di isi oleh 5 narasumber dalam hal ini kabag pada PG Trangkil. Bentuk kuesioner yang digunakan mengacu pada model AHP dengan memilih tingkat kepentingan mengenai seberapa green proses dan kinerja rantai pasok serta kinerja keuangan perusahaan.

Alat yang digunakan dalam penelitian ini adalah sistem operasi Microsoft Windows 7 dan perangkat lunak untuk pengolahan data dan pembuatan interface menggunakan PHP dan MySQL. Sedangkan perangkat keras mengunakan Processor Intel (R) Core 2 Duo, RAM $1 \mathrm{~Gb}$, HDD $160 \mathrm{~Gb}$.

\subsection{Prosedur Penelitian}

Dalam penelitian ini, ada beberapa tahapan prosedur penelitian yang dilakukan untuk memastikan agar supaya mencapai hasil yang maksimal dan mudah untuk di imlementasikan. Adapun gambaran dari tahapan prosedur penelitian seperti pada Gambar 1 . Sedangkah langkah selanjutnya adalah penyusunan dan pengkelompokan KPI ke dalam proses rantai pasok yang ramah lingkungan. Berikut ini adalah proses rantai pasok ramah lingkungan yang ada di PG Tarangkil, meliputi pengadaan, produksi, pengiriman, dan pengembalian. Kegiatan GSCM dapat di lihat seperti pada Gambar 2.

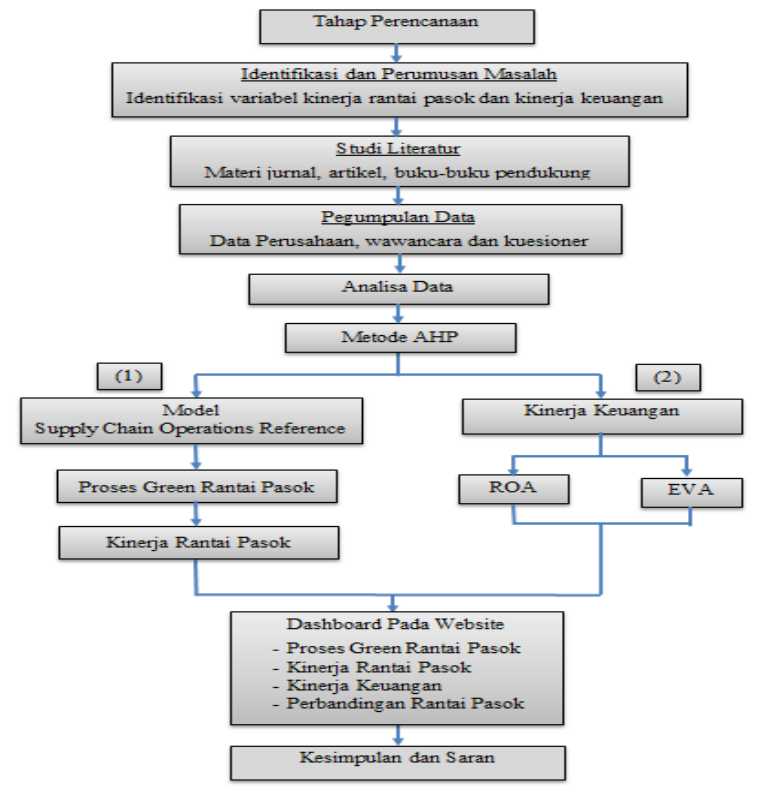

Gambar 1. Tahapan prosedur penelitian

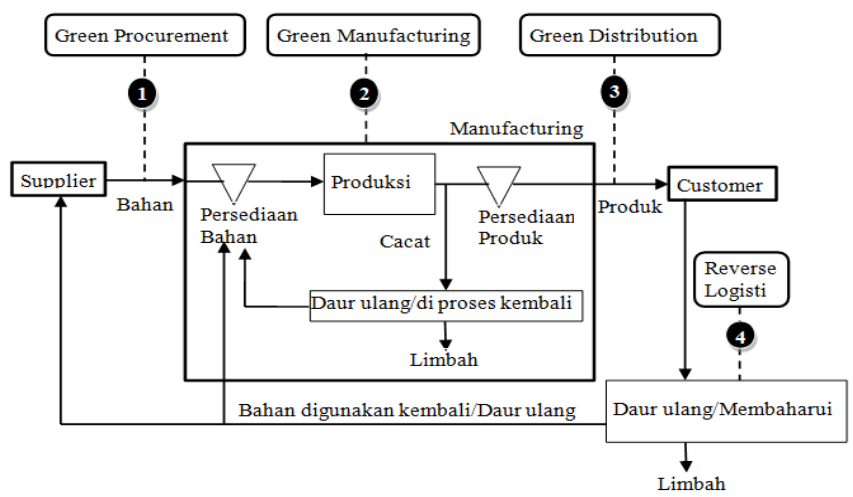

Gambar 2. Kegiatan manajemen rantai pasok ramah lingkungan

1. Pengadaan Ramah Lingkungan

Merupakan bagian dari proses green Procurement yang meliputi kegiatan pemiliah bahan ketel tebu yang sudah terseleksi oleh bagaian QC, pemilihan zat-zat kimia yang digunakan harus bersertifikat ISO 14000, bahan untuk karung pembungkus dari daur ulang, pesanan pengadaan dilakukan lewat email sehingga paperless. Maka KPI dari proses pengadaan yang ramah lingkungan, seperti pada Tabel 2 berikut.

Tabel 2. KPI Pengadaan yang Ramah Lingkungan

\begin{tabular}{lll}
\hline Kriteria & Kode & \multicolumn{1}{c}{ KPI } \\
\hline & SI & Bahan lolos Quality Control. \\
Pengadaan & S2 & Zat kimia berstandart ISO 14000. \\
& S3 & Menggunakan daur ulang karung. \\
& S4 & Order via email. \\
\hline
\end{tabular}


2. Produksi Ramah Lingkungan

Merupakan proses dari Green manufacturing yang meliputi produk harus berkwalitas bahkan diatas standart supaya tidak terjadi banyak pengembalian dan kerusakan. Produk yang di buat harus bebas dari zat timbal seperti perak dan timah. Mampu menyelesaikan lebih cepat dari yang di rencanakan sehingga tidak ada waktu kosong yang terbuang dan akhirnya output yang dihasilkan meningkat atau melampaui target. Terjadi efesiensi bahan sehingga akan menghasilkan sedikit bahkan tidak ada limbah atau polusi dan akhirnya bisa mengurangi biaya bahan baku. Dari kriteria diatas diharapkan dapat mengurangi beban keselamatan lingkungan dan pekerjaan sehingga dapat meningkatkan citra perusahaan. Adapun KPI dari proses produksi yang ramah lingkungan pada PG Trangkil seperti pada Tabel 3 berikut ini :

Tabel 3. KPI Produksi yang Ramah Lingkungan

\begin{tabular}{lll}
\hline Kriteria & Kode & \multicolumn{1}{c}{ KPI } \\
\hline & M1 & Produk Berkwalitas \\
Produksi & M2 & Bebas zat timbal \\
& M3 & Waktu lebih cepat dari target \\
& M4 & Efesiensi bahan \\
\hline
\end{tabular}

\section{Pengiriman Ramah Lingkungan}

Merupakan proses dari green distribution yang secara umum meliputi, Pengiriman lebih cepat dari yang di tentukan dan dalam keadaan sempurna baik barang maupun dukumennya, mengunakan kendaraan berbahan bakar alternatif seperti solar bersubsidi dan bio fuel kerja sama dengan pabrik tepung tapioka di Margoyoso-Ngemplak Pati, mendistribusikan produk dalam skala besar dan langsung ke distributor tidak ke pengecer, desain kemasan fleksibel dari kemasan seperti ukuran, bentuk, dan bahan yang bisa berdampak pada distribusi karena dapat mempengaruhi transportasi, meningkatkan pemanfaatan ruang di gudang dan di trailer. Adapun KPI dari pengiriman yang ramah lingkungan pada PG Trangkil seperti pada tabel 4 berikut.

Tabel 4. KPI Pengiriman yang Ramah Lingkungan

\begin{tabular}{lll}
\hline Kriteria & Kode & \multicolumn{1}{c}{ KPI } \\
\hline \multirow{3}{*}{ Pengiriman } & D1 & Pengiriman diatas target \\
D2 & Kendaraan berbahan bakar alternatif \\
D3 & Distribusi skala besar \\
D4 & Desain kemasan fleksibel \\
\hline
\end{tabular}

\section{Pengambalian Ramah Lingkungan}

Merupakan proses reverse logistics dari konsumen akhir. Secara umum meliputi produk yang dikembalian sudah di perbaharui sehingga tidak jadi barang sampah, penggunaan kebali limbah baik ampas tebu di gunakan untuk pupuk dan untuk campuran bahan bata, serta karung bekas dari distributor di daur ulang dan di sablon kembali, serta sedikit bahkan tidak ada pengembalian dari konsumen. Jadi KPI proses pengembalian yang ramah lingkungan pada PG Tarangkil seperti pada Tabel 5 berikut ini.

Tabel 5. KPI Pengembalian yang Ramah Lingkungan

\begin{tabular}{rll}
\hline Kriteria & Kode & \multicolumn{1}{c}{ KPI } \\
R1 & Memperbaharui produk \\
Pengembalian R2 & Daur Ulang Limbah \\
R3 & Minimal Pengembalian \\
\hline
\end{tabular}

Langkah selanjutnya adalah pengolahan data, hasil dari setiap KPI yang telah tersusun dalam sebuah hirarki, kemudian diberi pembobotan dengan menggunakan metode AHP. Tujuan dari pembobotan adalah untuk mendapatkan bobot tingkat kepentingan atau seberapa besar KPI berpengaruh terhadap kinerja rantai pasok.

5. Pengelompokan Kinerjan Rantai Pasok

Berikut ini kriteria-kriteria kinerja yang ada dalam model Green SCOR :

a. Kehandalan (Reliability)

Presentase pengiriman gula dengan lengkap dan dokumentasi yang akurat, tidak ada kerusakan ke tempat distributor dengan waktu dan kwalitas yang tepat sesuai pesanan. Serta peningkatan jaringan kerja untuk mereduksi limbah dan efisiensi operasi.

b. Daya tangkap (Responsiveness)

Respon untuk menyiapkan gula yang siap dikirim kepada distributor. Dengan rata-rata waktu siklus selalu konsisten untuk memenuhi permintaan pelanggan yang dimulai dari penerimaan order sesuai dengan urutan. Serta memperhatikan dampak yang mempengarui kecepatan pengiriman dan regulasi.

c. Mudah menyesuaikan (Aglity) Kemampuan pabrik gula dalam merespon perubahan produk, perubahan pasar dan perubahan lingkungan untuk mendapatkan keunggulan kompetitif.

d. Biaya (Cost)

Semua biaya langsung dan tidak langsung yang berhubungan dengan seluruh operasi rantai pasokan secara green. Biaya yang terkait dengan membeli bahan baku dan memproduksi barang jadi yang mengacu pada (eco desing) desain ramah lingkungan. Biaya ini meliputi biaya langsung (tenaga kerja dan bahan) serta biaya tidak langsung untuk mendapatkan (long-term profitability) keuntungan jangka panjang.

e. Managemen Aset (Asset Management) Merupakan keefektifan pabrik gula dalam mengatur asetnya untuk memenuhi permintaan secara green (Ekonomis dan efesien sumber daya). Baik berupa permodalan antara lain lahan tebu dan alat giling.

f. Ramah Lingkungan (Green)

Dimensi pengukuran kinerja ditambahkan dengan aspek lingkungan dan faktor efektif 
dikarenakan menggunakan pendekatan SCOR yang berbasis "green" (Green SCOR).

6. Komponen Kinerja Keuangan

Sedangkan indikator dari kinerja rantai pasok untuk mengukur kinerja keuangan perusahaan meliputi :

a. Pendapatan (revenue).

Pendapatan didalam kriteria model SCOR di peroleh dari pemenuhan pesanan yang sempurna dan siklus waktu pemenuhan pesanan yang baik

b. Biaya (cost).

Biaya yang ditangung oleh perusahaan adalah jika ada kenaikan fleksibilitas rantai pasok, ada kenaikan dan kelemahan adaptasi rantai pasok jadi butuh biaya penyesuaian, nilai keseluruhan dari kerusakan, biaya manajemen rantai pasokan, harga pokok penjualan.

c. Aset (assets).

Aset perusahan di peroleh dari waktu siklus kas ke kas yang baik serta adanya pengembalian aktiva tetap untuk perusahaan, dan memperoleh laba atas modal kerja yang di gunakan.

Pengukuran kinerja keuangan dengan pendekatan Green SCOR akan menghasilkan hubungan antar indikator kinerja rantai pasok dengan indikator kinerja keuangan seperti pada Tabel 6 di bawah ini :

Tabel 6. Hubungan Antara Kinerja Rantai Pasok dengan Kinerja Keuangan

\begin{tabular}{|c|c|c|c|c|c|c|c|}
\hline \multirow{3}{*}{\begin{tabular}{|l|} 
\\
SCOR metrik strategi rantai pasol \\
\end{tabular}} & \multicolumn{5}{|c|}{ Atribut Kinejaja Rantai Pasolk } & \multicolumn{2}{|c|}{ Merik Kinerja Kevangan } \\
\hline & \multicolumn{3}{|c|}{ Faktor Konsumen } & \multicolumn{2}{|c|}{ FaltorIntemal } & \multirow{2}{*}{$\begin{array}{l}\text { Komponen } \\
\text { EVA }\end{array}$} & \multirow{2}{*}{$\begin{array}{l}\text { Du pont } \\
\text { Analysis }\end{array}$} \\
\hline & Reliabilitas & Responsivitis & Fleksibilitas & Biaya & Asset & & \\
\hline Pemenuhan pesanan sempuma & & & & & & \multirow{2}{*}{ Pendapatan } & \multirow{2}{*}{$\begin{array}{c}\text { Faltor } \\
\text { Keuntungan } \\
\text { dan Efisiensi }\end{array}$} \\
\hline Sikus waktu pemenuban pesanan & & & & & & & \\
\hline Kenaikan Fleksibilitas rantai pasok & & & & & & \multirow{6}{*}{ Biaya } & \multirow{6}{*}{$\begin{array}{c}\text { Faltor } \\
\text { Keuntungan }\end{array}$} \\
\hline Kenaikan adaptasi rantai pasols & & & & & & & \\
\hline Kelemahan adaptasi rantai pasolk & & & & & & & \\
\hline Nilai keseluruhan dari kerusalan & & & & & & & \\
\hline Biaya manajemen rantai pasolk & & & & & & & \\
\hline Harga Pokok Penjualan & & & & & & & \\
\hline Waltu silibus las ke las & & & & & & \multirow{3}{*}{ Aset } & \multirow{3}{*}{$\begin{array}{l}\text { Faltor } \\
\text { Effisiensi }\end{array}$} \\
\hline Pengembalian aktiviva tetap rantai pasolan & & & & & & & \\
\hline Laba atas modal kerja & & & & & & & \\
\hline
\end{tabular}

\subsection{Hubungan Antar Metode yang Digunakan}

Berikut ini adalah langkah-langkah hubungan antara metode yang digunakan untuk meningkatkan kinerja rantai pasok dan kinerja keuangan perusahaan.

1. Pertama dari KPI proses kinerja rantai pasok yang ramah lingkungan di hitung mengunakan metode AHP untuk mengetahui berapa bobot masingmasing antar kriteria ramah lingkungan atau green pada PG Trangkil.

2. Menghubungkan proses kinerja rantai pasok yang ramah lingkungan dengan kinerja rantai pasok, ada lima kriteria kepentingan pada kinerja Green SCOR yang digunakan. Kemudian menghubungkannya dengan tiga faktor kinerja keuangan menggunakan metode AHP.

3. Meghitung dan menganalisa indikator keuangan untuk mendapatkan indek keuangan perusahaan dengan mengunakan ROA dan EVA.

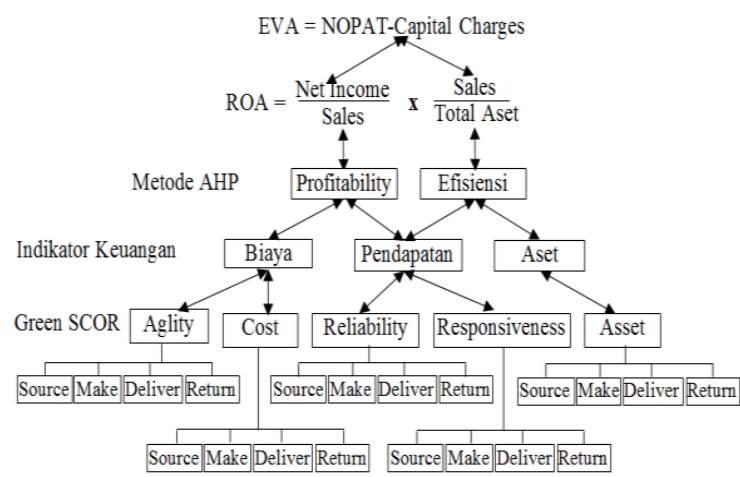

Gambar 3. Hubungan antar metode yang digunakan

\section{Hasil dan Pembahasan}

\subsection{Hasil Penelitian}

Penerapan metode AHP pada penelitian ini adalah untuk mencari bobot atau indeks setiap kriteria dari kinerja keuangan, kinerja rantai pasok dan dari proses rantai pasok yang ramah lingkungan. Karena mengacu pada kuesioner model AHP jadi ditentukan pilihan skala masing-masing kriteria pada setiap pertanyaan dan selanjutnya responden diminta memilih salah satu kriteria dengan pilihan skala 1 sampai 9. Hasil kuesioner dari responden di proses menggunakan metode AHP. Prosedur dari metode AHP adalah dengan menghitung rata-rata geometric dari responden, menghitung matriks perbandingan berpasangan, menghitung bobot kriteria dan KPI, mencari eigen vektor, menghitung indek konsistensi dan menghitung rasio konsistensi.

Model SCOR digunakan untuk menentukan kriteria kinerja rantai pasok. Selain itu juga model SCOR mampu menghubungkan antara kinerja rantai pasok dengan kinerja keuangan. Model SCOR juga sudah memiliki KPI tetap, maka dari KPI tersebut kemudian administrator tinggal memasukkan datadata riil perusahaan. Setelah data di inputkan dan target di tentukan oleh perusahaan akan di ketahui KPI mana saja yang kerjanya efektif atau bisa memenui target. Serta KPI mana saja yang belum memenui taget dan butuh perhatian dari perusahaan. Karena setelah data tersebut diproses maka akan dihasilkan bobot masing-masing KPI dan bobot masing-masing kriteria kinerja rantai pasok.

Dalam kinerja keuangan indikator yang digunakan pada penelitian ini adalah dengan mengunakan ROA dan EVA. Langkah pertama pada metode ini adalah dari data keuangan pabrik akan dihitung mengunakan rumus ROA sehingga akan menghasilkan indek laba pabrik dan apakah masuk kedalam kategori sehat, cukup sehat, kurang sehat atau malah tidak sehat. 
Karena ROA adalah untuk mengetahui seberapa besar pengembalian aset atas perusahaan.

Pada langkah yang ke dua yaitu dengan cara mencari EVA perusahaan supaya mengetahui seberapa jauh efektifitas perusahaan dalam beroperasi. Maka dari data keuangan di hitung mengunakan rumus EVA untuk menghasilkan indikator pabrik apakah pada posisi baik, impas atau tidak sehat. Hasil dari sistem ini dapat dijadikan saran bagi perusahaan agar lebih maksimal dalam mengelola kinerja rantai pasok dan strategi keuangan perusahaan. Sehingga akan dihasilkan output dari sistem ini yaitu prioritas kinerja keuangan, bobot kepentingan kinerja rantai pasok yang di bandingkan dengan hasil riil kinerja rantai pasok, indeks proses rantai pasok yang ramah lingkungan, indek ROA serta EVA perusuhaan. Semua output ditampilkan dalam bentuk tabel dan grafik. Kerangka hasil sistem informasi GSCM seperti pada Gambar 4 berikut.

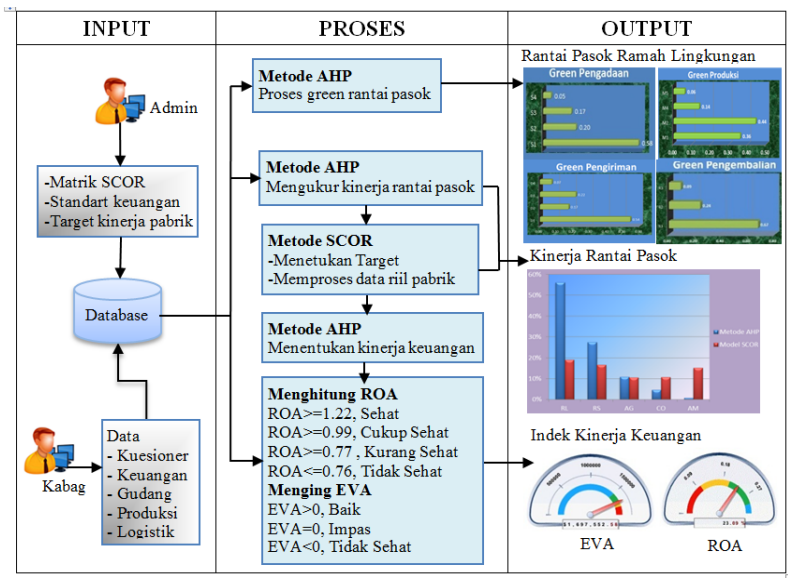

Gambar 4. Kerangka hasil penelitian sistem informasi

Dari kerangka sistem informasi ini akan dihasilkan output dari sistem ini yaitu indeks proses rantai pasok yang ramah lingkungan untuk kriteria pengadaan dengan alternatif (S1) Bahan lolos Quality Control = $58 \%$, (S2) Zat kimia berstandart ISO $14000=20 \%$, (S3) Menggunakan daur ulang karung $=17 \%$ dan (S4) Order via email $=5 \%$. Jadi untuk proses pengadaan yang order via email perlu perhatian dan peningkatan karena masih sedikit.

Kriteria produksi dengan alternatif (M1) Produk Berkwalitas $=36 \%$, (M2) Bebas zat timbal $=44 \%$, (M3) Waktu lebih cepat dari target $=14 \%$ dan (M4) Efesiensi bahan $=6 \%$. Secara umum proses produksi sudah berjalan baik hanya pada efesiensi bahan yang perlu di tingkatkan lagi supaya hasilnya lebih maksimal.

Kriteria pengiriman dengan alternatif (D1) Pengiriman diatas target $=54 \%$, (D2) Kendaraan berbahan bakar alternatif $=17 \%$, (D3) Distribusi skala besar $=22 \%$ dan (D4) Desain kemasan fleksibel $=7 \%$. Kriteria pengembalian dengan alternatif (R1)
Memperbaharui produk $=67 \%$, (R2) Daur Ulang Limbah $=24 \%$ dan (R3) Minimal pengembalian $=9 \%$. Jadi secara umum proses pengiriman dan pengembalian sudah berjalan baik dan dapat dikatakan ramah lingkungan. Sedangkan bobot kinerja rantai pasok untuk kriteria reliability $=56 \%$, responsiveness $=28 \%$, Aglity $=11 \%$, Cost $=5 \%$ dan Asset Management $=1 \%$. Hasil kinerja tersebut kemudian di bandingkan dengan hasil riil kinerja rantai pasok dan jika di konfersi dalam prosentase untuk reliability mendapat $=32 \%$, responsiveness $=31 \%$, Aglity $=$ $14 \%$, Cost $=9 \%$ dan Asset Management $=15 \%$. Maka ada 2 kriteria yang harus di evaluasi yaitu pada reliability yang belum memenuhi target perusahaan dan pada Asset Management yang terlalu besar dikeluarakan dari yang sudah di tentukan.

Selanjutnya untuk indek kinerja keuangan, perusahaan menetapkan profitability $87,3 \%$ dan efeciency $12,7 \%$. Jika kemudian dibandingkan dengan hasil riil indek EVA perusahaan 130.893.000.000 serta ROA sebesar 16,4\%. Jadi bisa dikatakan keuntungan perusahaan melebihi target Rp.23.331.000.000 dan pengembalian atas aset perusahaan melebihi target 3,7\%. Artinya dalam hal ini metode Du Pont Rasio Analysis mampu menganalisa dan mengevaluasi kinerja keuangan supaya lebih efektif

\subsection{Pembahasan}

Pada penelitian ini dibahas tentang penilaian kinerja rantai pasok ramah lingkungan dan penilaian kinerja keuangan perusahaan yang terdiri dari front end sistem dan back end sistem. Front end ada 5 kabag pabrik sebagai responden yang akan memasukkan data kuesioner model AHP. Kuesioner tersebut untuk mencari bobot dari masing-masing kriteria. Back end sistem dikelola oleh administrator dalam manajemen konten, menggelola data, memasukan data pabrik, standart dan target perusahaan sesuai model SCOR. Hasilnya adalah performance green rantai pasok dan level kinerja keuangan.

\subsubsection{Tahap Pembobotan dengan Metode AHP}

Setiap KPI yang telah tersusun dalam sebuah hirarki, kemudian diberi pembobotan dengan menggunakan metode AHP. Tujuan dari pembobotan ini adalah untuk mendapatkan bobot tingkat kepentingan atau seberapa besar KPI berpengaruh terhadap penilaian kinerja rantai pasok dan kinerja keuangan perusahaan. Serta sebagai bahan acuan untuk strategi perusahaan yang akan digunakan.

\section{Pembobotan dari masing-masing kriteria}

Langkah pertama adalah menghitung tingkat kepentingan perbandingan berpasangan masingmasing kriteria. Adapun data kepentingan perbandingan berpasangan antar kriteria dapat dilihat pada Tabel 7 berikut ini : 
Tabel 7. Koesioner para ahli menentukan prioritas kinerja keuangan

\begin{tabular}{cccccc}
\hline Kriteria & Kabag 1 & Kabag 2 & Kabag 3 & Kabag 4 & Kabag 5 \\
\hline P dan E & 7 & 5 & 7 & 7 & 9 \\
\hline
\end{tabular}

\section{Menghitung tingkat kepentingan perbandingan} berpasangan

Dalam metode AHP menghitung tingkat kepentingan perbandingan berpasangan antar kriteria. digunakan rata-rata geometrik dari penilaian yang diberikan oleh 5 narasumber.

$$
G M=\sqrt[5]{7} \times 5 \times 7 \times 7 \times 9
$$

$$
=6.88
$$

Tabel 8. Rata-rata geometrik kinerja keuangan

\begin{tabular}{lcc}
\hline \multicolumn{1}{c}{ Kriteria } & Profitability & Efficiency \\
\hline Profitability & 1 & 6.88 \\
Efficiency & 0.15 & 1 \\
\hline
\end{tabular}

Di mana 6.88 adalah nilai rata-rata sedangkan 0,15 adalah nilai kebalikan dari Geometrik. Selanjutnya untuk matriks perbandingan berpasangan, mencari eigen vector dengan mengunakan perhitungan bobot dan prioritas dari kinerja keuangan faktor ditentukan sebagai berikut:

Tabel 9. Bobot matrik kinerja keuangan

\begin{tabular}{lccc}
\hline \multicolumn{1}{c}{ Kriteria } & Profitability & Efficiency & Bobot \\
\hline Profitability & 0.873 & 0.873 & 0.873 \\
Efficiency & 0.127 & 0.127 & 0.127 \\
Jumlah & 1.000 & 1.000 & 1.000 \\
\hline
\end{tabular}

Jadi untuk perusahaan ini, prioritas yang lebih tinggi untuk meningkatkan kinerja keuangan diberikan kepada faktor profitabilitas dengan bobot prioritas dari $87,3 \%$ dibandingkan dengan hanya $12,7 \%$ diberikan untuk faktor efisiensi.

\section{Mencari konsistensi rasio}

Langkah selanjutnya adalah menghitung Consistensi Rasio (CR) untuk mengetahui seberapa konsisten jawaban para responden dalam mengisi koesioner.

Tabel 10. Konsistensi rasio

\begin{tabular}{lcccc}
\hline Kriteria & Profitability & Efficiency & Bobot & Hasil Kali \\
\hline Profitability & 1 & 6.9 & 0.873 & 1.746 \\
Efficiency & 0.15 & 1 & 0.127 & 0.254 \\
\hline
\end{tabular}

Setelah diperoleh perhitungan konsistensi di atas, dilakukan perhitungan Consistency Vector sebagai berikut :

$1.746 / 0.873=2$

$0.254 / 0.125=2$

Maka rata - rata kedua entri terakhir, yaitu :

$$
\lambda_{\text {maks }}=\frac{2+2}{2}=2
$$

$\mathrm{n}$ adalah jumlah orde matriks, pada kasus ini adalah matriks berorde 2, maka Consistency Index-nya adalah :

$$
C I=\frac{\lambda_{m a k s}-n}{n-1}=\frac{2-2}{2-1}=
$$

Langkah selanjutnya adalah menghitung Consistensi Rasio (CR), dimana Random Index (RI) dengan $\mathrm{n}=2$ adalah 0.00 (diperoleh dari tabel random indeks), maka nilai $\mathrm{CR}$ adalah :

$C R=\frac{C I}{I R}=\frac{0.00}{0} 0$

Hasil perhitungan nilai di atas adalah $\mathrm{CR} \leq 0,1$ untuk matriks 2x2 maka dapat disimpulkan bahwa narasumber pada kuesioner ini konsisten terhadap jawabannya.

\section{Matrik perbandingan berpasangan antar masing- masing kriteria}

Pada tahap ini adalah untuk mengetahui bobot masing-masing setiap alternatif setelah pengaruh dari prioritas kinerja keuangan. Sedangkan untuk mengetahui bobot alternatif pada kriteria profitability langkah-langkahnya adalah seperti berikut.

Tabel 11. Matrik perbandingan antar alternatif kriteria profitability

\begin{tabular}{ccccc}
\hline Kriteria & RL & RS & AG & CO \\
\hline RL & 1 & 3.32 & 5.35 & 6.54 \\
RS & 0.30 & 1 & 4.36 & 5.35 \\
AG & 0.19 & 0.23 & 1 & 4.08 \\
CO & 0.15 & 0.19 & 0.25 & 1 \\
Jumlah & 1.64 & 4.74 & 10.95 & 16.97 \\
\hline
\end{tabular}

Dari hasil penjumlahan matriks perbandingan berpasangan di atas, selanjutnya dihitung matriks normalisasi seperti pada Tabel 12 dengan cara membagi masing-masing angka di setiap kolom dengan jumlah kolom masing-masing dan dilanjutkan dengan menghitung nilai rata-rata di masing-masing baris.

Tabel 12. Matriks normalisasi dan rata-rata baris untuk kriteria profitability

\begin{tabular}{cccccc}
\hline Kriteria & RL & RS & AG & CO & Bobot \\
\hline RL & 0.61 & 0.70 & 0.49 & 0.39 & 0.55 \\
RS & 0.18 & 0.21 & 0.40 & 0.32 & 0.28 \\
AG & 0.11 & 0.05 & 0.09 & 0.24 & 0.12 \\
CO & 0.09 & 0.04 & 0.02 & 0.06 & 0.05 \\
Jumlah & 1.00 & 1.00 & 1.00 & 1.00 & 1.00 \\
\hline
\end{tabular}

Jadi diperoleh bobot kriteria alternatif profitability untuk (RL) Reliability 0.55, (RS) Responsiveness 0.28, (AG) Aglity 0,12 dan (CO) Cost 0.05.

Sedangkan langkah-langkah untuk mengetahui bobot masing-masing alternatif pada kriteria 
efficiency setelah pengaruh dari prioritas kinerja keuangan seperti berikut.

Tabel 13. Matrik perbandingan antar alternatif kriteria efficiency

\begin{tabular}{cccc}
\hline Kriteria & RL & RS & AM \\
\hline RL & 1 & 3.68 & 7.74 \\
RS & 0.27 & 1 & 5.72 \\
AM & 0.13 & 0.17 & 1 \\
Jumlah & 1.40 & 4.85 & 14.46 \\
\hline
\end{tabular}

Setelah matriks tersebut dihitung dengan cara membagi masing-masing angka di setiap kolom dan jumlah kolom kemudian dilanjutkan dengan menghitung nilai rata-rata di masing-masing baris, yang diperoleh bobot masing-masing alternatif kriteria efficiency untuk (RL) Reliability 0.67, (RS) Responsiveness 0.27 dan (AM) Asset Management 0.07 .

\section{Mencari skor total setiap alternatif}

Setelah diperoleh bobot masing-masing alternatif dan di jumlahkan antara alternatif profitability dan efficiency, maka tinggal mengalikan dengan hasil bobot dari kriteria profitability dan efficiency dan akan menghasilkan skor total

dari setiap alternatif. Selain itu juga bisa ditentukan rangking masing-masing kriteria alternatifnya, seperti pada Tabel 14 berikut ini.

Tabel 14. Total skor setiap alternatif

\begin{tabular}{lcc}
\hline Kriteria & W (Bobot) & Rangking \\
\hline (RL) Reliability) & 0.56 & 1 \\
(RS) Responsiveness) & 0.28 & 2 \\
(AG) Aglity & 0.11 & 3 \\
(CO) Cost & 0.05 & 4 \\
(AM) Asset Management & 0.01 & 5 \\
\hline
\end{tabular}

\subsubsection{Pengolahan Data Keuangan}

Berikut ini adalah data keuangan dari PG Trangkil periode I sampai pada bulan April 2014. Dari hasil produksi gula sebanyak 637.000 ton, jika 1 ton sama dengan $100 \mathrm{~kg}$ sedangkan harga gula per kg Rp.11.000 pada periode ini dan total biaya yang dikeluarkan sebesar $67 \%$ dari total aset manajemen yang dimiliki pabrik, maka akan didapat data keuangan secara global dari jumlah total laba penjualan, jumlah total biaya yang di keluarkan, jumlah total laba kotor yang diperoleh dan jumlah total aset yang dimiliki perusahaan seperti pada Tabel 15 berikut.

Tabel 15. Data Keuangan Perusahaan

\begin{tabular}{ll}
\hline Keterangan & Jumlah Total \\
\hline Penjualan & Rp. $700,700,000,000,00$ \\
Biaya & Rp.562,800,000,000,00 \\
Laba & Rp. $137,900,000,000,00$ \\
Aset & Rp.840,000,000,000,00 \\
\hline
\end{tabular}

Dari data diatas di analisa dan diolah dengan mengunakan metode Du Pont Rasio Analysis untuk menentukan seberapa besar laba dan pengembalian aset pabrik pada periode pertama ini. Maka dilakukan perhitungan dengan mengunakan rumus ROA. Langkah-langkahnya adalah sebaga berikut :

$\mathrm{ROA}=$ Net Profit Margin $x$ Total Assets Turnover (9) $=($ Net Income $/$ Sales $) x$ (Sales/Total Assets $)$

$$
\mathrm{ROA}=\frac{137,900,000,000}{700,700,000,000} \times \frac{700,700,000,000}{840,000,000,000}=0.164
$$

Jadi dari proses tersebut di peroleh ROA (Return On Assets) pabrik sebesar 0.164 atau sama dengan $16,4 \%$ maka dapat dikatakan posisi keuangan perusahan pada periode ini dalam kedaan sehat.

Selanjutnya untuk mencari nilai tambah bagi perusahaan. Masih dari data keungan pabrik seperti pada Tabel 16 diatas serta pajak sebesar 1\% dari laba kotor yang harus dibayarkan kepada pemerintah. Maka analisa proses yang dilakukan yaitu dengan mengunakan rumus EVA (Economic Value Added). Langkah-langkah perhitungan adalah sebagai berikut :

$$
\begin{aligned}
& \text { NOPAT }=\text { Laba Kotor }- \text { Pajak } \\
& \begin{aligned}
\text { NOPAT } & =700,700,000,000-7,007,000,000 \\
& =693,693.000 .000
\end{aligned}
\end{aligned}
$$

Capital Charges $=$ Total biaya modal

Sedangkan total biaya modal yang dikeluarkan oleh perusahaan dalam periode ini sebesar $67 \%$ dari aset manajemen yang di miliki.

$$
\begin{aligned}
\text { Maka Capital Charges } & =67 / 100 \times 840,000,000,000 \\
& =562,800,000,000
\end{aligned}
$$

EVA $=$ NOPAT - Capital Charges

$$
\begin{aligned}
& =693,693.000 .000-562,800,000,000 \\
& =130,893,000,000
\end{aligned}
$$

Jadi dari proses analisa tersebut di atas di peroleh hasil penilaian kinerja keuangan pabrik dengan mengunakan EVA sebasar Rp. 130,893,000,000 jadi lebih besar 0 maka dapat dikatakan kinerja keuangan pabrik dalam keadaan baik. Karena kreditur tetap mendapat bunga dan pemilik saham bisa mendapatkan pengembalian yang sama atau lebih dari yang ditanam.

\section{Kesimpulan}

Berdasarkan uraian di atas, maka dapat diambil kesimpulan bahwa GSCM dapat memberikan informasi dan pengaruh terhadap kinerja rantai pasok dan indek kinerja keuangan. Proses rantai pasok di nilai kinerjanya dengan mengunakan lima kriteria 
yang ada pada Green SCOR dan di hubungkan dengan kinerja keuangan, kemudian dianalisa untuk mencari bobot masing-masing kriteria mengunakan metode AHP. Dari hasil analisa kemudian dibandingkan dengan hasil riil sistem SCOR, supaya bisa dievaluasi, dikontrol dan dimonitoring.

Karena hasil analisis yang diperoleh menunjukkan bahwa proses produksi, pengiriman dan pengembalian sudah berjalan baik dan dapat dikatakan ramah lingkungan. Hanya pada proses pengadaan yang order via email perlu perhatian dan peningkatan karena masih sedikit yang mengunakan cara ini. Juga ada 2 kriteria yang harus di evaluasi yaitu pada reliability yang belum memenuhi target perusahaan dan pada Asset Management yang terlalu besar dikeluarakan dari yang sudah di tentukan.

Bahkan keuntungan perusahaan melebihi target sebesar Rp.23.331.000.000 dan pengembalian atas aset perusahaan melebihi target 3,7\% dari yang sudah ditentukan. Artinya dalam hal ini metode yang digunakan mampu menganalisa dan mengevaluasi kinerja perusahaan dan keuangan lebih efektif.

\section{Ucapan Terima Kasih}

Terima kasih diucapkan pada PG Trangkil Pati yang telah memberikan data dalam penelitian ini.

\section{Daftar Pustaka}

Chen, C.C., Shih, H.S., Shyur, H.J., Wu, K.S., 2012. A business strategy selection of green supply chain management via an analytic network process, Computers and Mathematics with Applications 64, $2544-2557$
Delen, D., Kuzey, C., Uyar, A., 2013. Measuring firm performance using financial ratios: A decision tree approach, Expert Systems with Applications 40, 3970-3983

Giovanni, P.D., Vinzi, V.E., 2012. Covariance versus component-based estimations of performance in green supply chain management, Int. J. Production Economics 135, 907-916

Kurien, G.P., Qureshi, M.N., 2012. Performance measurement systems for green supply chains using modified balanced score card and analytical hierarchical process, Academic Journals 36, 149161

Póvoa, B., Cardoso, S.R., Paula, F.D., 2013. Design and planning of supply chains with integration of reverse logistics activities under demand uncertainty, European Journal of Operational Research 226, 436-451

Supply chain council., 2010. Supply Chain Operations Reference (SCOR) model, www.supply-chain.org, United States and Europe.

Tipi, N.S., Hubbard, N. J., Leach, D.Z., 2012. Linking supply chain processes' performance to a company's financial strategic objectives, European Journal of Operational Research 223, $276-289$

Wang, X., Chan, H.K., Rachel W.Y., Rainey, I.D., 2012. A two-stage fuzzy-AHP model for risk assessment of implementing green initiatives in the fashion supply chain, Int. J. Production Economics 135, 595-606

Wilkerson., Taylor., 2003. LMI, GreenSCOR: Developing a Green Supply Chain Analytical Tool, Logistics Management Institute, Washington, DC, 8-98 